\author{
STEFAN STOJALOWSKI ${ }^{1}$ \\ MARTA ORLOWSKA ${ }^{1}$ \\ MARTYNA SOBCZYK ${ }^{1}$ \\ ANNA BIENIAS ${ }^{1}$ \\ BEATA MYŚKÓW ${ }^{1}$ \\ MARZENA OSTROWSKA ${ }^{2}$ \\ MAREK ZAJACC ${ }^{2}$ \\ RÓŻA MAZUR ${ }^{2}$ \\ DOROTA JASIŃSKA ${ }^{2}$ \\ ${ }^{1}$ Katedra Genetyki, Hodowli i Biotechnologii Roślin, Zachodniopomorski Uniwersytet Technologiczny \\ w Szczecinie \\ ${ }^{2}$ Poznańska Hodowla Roślin Sp. z o.o. \\ Kierownik Tematu: dr hab. Stefan Stojałowski prof. ZUT Katedra Genetyki, Hodowli i Biotechnologii \\ Roślin, Zachodniopomorski Uniwersytet Technologiczny w Szczecinie, Słowackiego 17, 71-434 Szczecin, \\ tel. 91 4496404, e-mail: stefan.stojalowski@zut.edu.pl
}

Prace zostały wykonane $w$ ramach badan podstawowych na rzecz postępu biologicznego $w$ produkcji roślinnej na podstawie decyzji Ministra Rolnictwa $i$ Rozwoju Wsi nr HOR.hn.802.13.2018, Zadanie 87.

\title{
Badania wewnętrznej struktury genetycznej odmian żyta oraz dziedzicznego podłoża efektu heterozji
}

\section{Study on internal genetic structure of rye cultivars and genetic background of heterosis}

Słowa kluczowe: efekt heterozji, odmiany populacyjne i mieszańcowe, żyto

Hodowla heterozyjna żyta została zapoczątkowana w latach 70. XX wieku, a rejestracja pierwszych odmian mieszańcowych miała miejsce w Niemczech w połowie lat 80. Strategia prac hodowlanych w Niemczech opracowana została na Uniwersytecie Hohenheim i od początku zakładała wydzielenie dwóch heterotycznych pul genetycznych (Geiger, 1985) dla komponentów matecznych (Petkus-pool) i ojcowskich (Carsten-pool). Początkowo hodowla komponentów rodzicielskich dla mieszańców polegała na tworzeniu linii wsobnych na drodze powtarzanego samozapylenia roślin reprezentujących obie pule genetyczne, następnie nowe linie wsobne tworzono w oparciu o mieszańce między wcześniej otrzymanymi najlepszymi (elitarnymi) liniami wsobnymi (Fischer i in., 2010). 
Jednoczesne krzyżowanie najlepszych linii wsobnych w obrębie jednej puli genetycznej $\mathrm{w}$ połączeniu $\mathrm{z}$ selekcją najlepszych genotypów nieuchronnie prowadzić musi do zawężenia zmienności genetycznej w obrębie heterotycznych pul (Duvick i in., 2004). W konsekwencji nieuniknione jest zahamowanie dalszego postępu biologicznego w hodowli mieszańców połączone ze wzrostem podatności odmian mieszańcowych na biotyczne i abiotyczne stresy środowiskowe. Dlatego też niezbędny jest systematyczny dopływ nowych genów do każdej z heterotycznych pul genowych. Realizacja tego zadania w sposób planowy wymaga wiedzy na temat struktury genetycznej aktualnie uprawianych i historycznych odmian, oceny wpływu zróżnicowania genetycznego na wartość gospodarczą populacji i szeregu innych badań.

Celami realizowanych badań była:

— ocena zmienności genetycznej występującej w obrębie odmian populacyjnych i mieszańcowych,

— ocena w warunkach polowych wartości gospodarczej populacji syntetycznych o zróżnicowanej strukturze genetycznej,

- wytworzenie pokolenia $\mathrm{S}_{3}$ linii introgresyjnych żyta.

Analizami genetycznymi objęto pięć odmian żyta - trzy populacyjne (Armand, Dańkowskie Granat i Horyzo) oraz dwie mieszańcowe (Skaltio F1 i Stakkatto F1). Do badań wykorzystano 90 losowo wybranych roślin z każdej odmiany. Przeprowadzono analizy z użyciem techniki DArTseq oferowanej przez firmę Diversity Arrays Technology Pty jako komercyjny wariant metody GBS (ang. Genotyping by Sequencing). Analizy podobieństwa genetycznego wykonywano w programie NTSys 2.2, a dendryty ilustrujące podobieństwo genetyczne skonstruowano w oparciu o wyniki DArTseq przy użyciu metody UPGMA. Analizy DArTseq dostarczyły informacji o 65534 markerach Silico-DArT. Zakres podobieństwa genetycznego między roślinami odmiany Armand mieścił się w granicach od 0,73 do 0,84. Dla odmiany Dańkowskie Granat zakres zmienności współczynników podobieństwa był bardzo podobny — od 0,74 do 0,83. W obu tych odmianach populacyjnych nie zaobserwowano obecności wyraźnie wydzielonych grup skupień. Odmiana Skaltio F1 charakteryzowała się najmniejszym wewnętrznym zróżnicowaniem genetycznym. Wartości współczynników podobieństwa genetycznego dla pojedynczych roślin tej odmiany mieściły się $\mathrm{w}$ granicach od 0,81 do 0,92. Nieznacznie większe wartości współczynników zmienności zaobserwowano u odmiany Stakkato F1, mieściły się one w granicach od 0,77 do 0,91 . W obu odmianach mieszańcowych najniższe wartości współczynników podobieństwa dotyczyły nielicznych roślin wykazujących odrębność od dominującej grupy genotypów charakterystycznej dla danej populacji. Ogólnie w odmianach populacyjnych badanych w 2018 roku obserwowano nieznacznie większą zmienność genetyczną niż w odmianach mieszańcowych.

Jesienią 2017 roku wysiano, w trzech powtórzeniach i w dwóch lokalizacjach (Wiatrowo, Nagradowice), doświadczenie polowe z sześcioma populacjami syntetycznymi żyta. Doświadczenie zaprojektowano w układzie bloków losowych, powierzchnia poletek wynosiła $5 \mathrm{~m}^{2}$. Jako wzorce odmianowe w doświadczeniu wykorzystano dwie odmiany mieszańcowe (Binnto F1 i Serafino F1) oraz jedną odmianę populacyjną - 
Antonińskie. W doświadczeniu wykorzystano też 6 eksperymentalnych mieszańców $\mathrm{F}_{1}$ z cytoplazmą Pampa. Łącznie badano 15 obiektów doświadczalnych. Oceniano plon ziarna $\mathrm{z}$ poletka (w przeliczeniu na wilgotność 15\%), wysokość roślin, wyleganie przed zbiorem oraz porażenie przez rdzę brunatną. Dwie wzorcowe odmiany mieszańcowe plonowały najlepiej ze wszystkich obiektów badanych w doświadczeniu. Poziom plonowania sześciu populacji syntetycznych był niski. Nawet najlepiej plonujące syntetyki SYN_4 i SYN_5 nie dorównywały odmianom wzorcowym (zarówno mieszańcowym, jak i odmianie populacyjnej Antonińskie). $\mathrm{W}$ porównaniu do kilku najsłabszych eksperymentalnych mieszańców $\mathrm{F}_{1}$, najlepsze syntetyki plonowały nieco lepiej. Najsłabiej plonującym obiektem doświadczenia był syntetyk SYN_3. Jego plon był o ponad połowę mniejszy niż plony dwóch wzorcowych odmian mieszańcowych.

Badane rośliny $\mathrm{z}$ populacji syntetycznych były względnie niskie. Ich wysokość była zbliżona do poziomu dwóch mieszańcowych odmian wzorcowych. Wzorzec populacyjny był wyraźnie wyższy od Binntto F1 i Serafino F1 oraz od badanych populacji syntetycznych. Najwyższym obiektem doświadczenia był jednak jeden z eksperymentalnych mieszańców $\mathrm{F}_{1}$ (LS_336P/15).

Wyleganie $\mathrm{w}$ doświadczeniach miało miejsce na bardzo niewielką skalę. Podczas eksperymentu polowego w Wiatrowie wylegania w ogóle nie zaobserwowano. Lekkie pochylenie roślin miało miejsce w Nagradowicach — w granicach od 7,3 do 8,0 w 9.punktowej skali bonitacyjnej.

W wyniku ścisłego chowu wsobnego, w stacji doświadczalnej Zachodniopomorskiego Uniwersytetu Technologicznego w Szczecinie uzyskano nasiona pokolenia $\mathrm{S}_{3}$ zestawu 90 linii introgresyjnych. Obserwowano objawy depresji wsobnej związane $\mathrm{z}$ wymuszonym samozapyleniem linii. Linie wysiano $\mathrm{w}$ polu w celu kontynuowania prac.

\section{WNIOSKI}

1. Badane odmiany populacyjne charakteryzowały się nieznacznie większym wewnętrznym zróżnicowaniem genetycznym niż odmiany mieszańcowe.

2. Wytworzone populacje syntetyczne plonowały słabo w porównaniu do odmian wzorcowych.

3. Zaobserwowano zróżnicowanie w wartości gospodarczej badanych syntetyków wyniki najlepsze i najgorsze otrzymano dla syntetyków dwuliniowych.

4. Wytworzony zestaw introgresyjnych linii wsobnych żyta $w$ pokoleniu $S_{3}$ charakteryzował się obniżoną żywotnością $\mathrm{W}$ porównaniu do mieszańca wyjściowego.

\section{LITERATURA}

Duvick D. N., Smith J. S. C., Cooper M. 2004. Long-term selection in a commercial hybrid maize breeding program. Plant Breed Rev 24: $109-151$. 
Fischer S., Melchinger A.E., Korzun V., Wilde P., Schmiedchen B., Möhring J., Piepho H.-P. Dhillon B. S., Wurschum T., Reif J. C. 2010. Molecular marker assisted broadening of the Central European heterotic groups in rye with Eastern European germplasm. Theor. Appl. Genet. 120: 291 - 299.

Geiger H. H. 1985. Hybrid breeding in rye. Proceedings of the EUCARPIA Meeting of the Cereal Section on Rye. Svalöv, Sweden, 11-13 June 1985: $237-265$. 